\title{
The Nexus Between Financial Development, Economic Growth and Poverty Alleviation: PMG-ARDL Estimation
}

\author{
Benjamin Korankye', Xuezhou Wen ${ }^{2 *}$, Michael Appiah ${ }^{3}$, Louisa Antwi ${ }^{4}$ \\ 1,3School of Management, Jiangsu University, China \\ ${ }^{2} S$ chool of Business, Jiangnan University, China \\ ${ }^{4}$ Southwestern University of Finance and Economics, China \\ E-mail: 'benjamin.korankye@yahoo.com, 2'wen_xuezhou@163.com, \\ 33dorscon2017@gmail.com, ‘antwilouisa97@yahoo.com
}

${ }^{*}$ Corresponding Author

\section{JEL Classification:}

G10

O47

I39

C33

Received: 05 June 2020

Revised: 28 August 2020

Accepted: 31 August 2020

\begin{abstract}
This study aims to find out the connections between financial development, economic growth, and poverty using panel data from 1985 to 2017 in fourteen African countries that many previous researchers ignore. The study deploys a dynamic Granger causality test to trace the nexus between financial development, economic growth, and poverty reduction in Africa in the long run. First, the upshots suggest a gross domestic product, gross capital formation, price of household consumption, and government expenditure substantially impacting poverty. Besides that, the result also shows a bi-directional in the long run using a PMG estimator. The findings broadly support the view that there is a stable, short-run relationship between financial development, economic growth, and poverty in the error correction terms. However, other variables show no causal relationship in the short run. In practicality, this study suggested some policy implications and supported governmental policies to reduce economic hardship on financial institutions.
\end{abstract}

\section{Keywords:}

financial development, economic growth, poverty reduction, developing countries

\section{How to Cite:}

Korankye, B., Wen, X., Appiah, M., \& Antwi, L. (2021). The Nexus Between Financial Development, Economic Growth, and Poverty Alleviation: PMG-ARDL Estimation. Etikonomi, 20(1), 1 - 12. https://doi.org/10.15408/ etk.v20i1.15908. 


\section{Introduction}

Many theories and empirical literature have extensively studied when it comes to the connection between financial development and economic growth. Many writers express the linkage between these variables discoursing about it on behalf of developing countries, including sub-Saharan Africa (Dhrifi, 2013; Sehrawat \& Giri, 2018; Kodongo \& Ojah, 2016; Uddin et al., 2014; Yang, 2019). Other studies suggested earlier literature cannot noticeably consider the connections of financial development, economic growth, and poverty reduction (Uddin et al., 2014). In their studies, they concluded financial development reduces poverty but not linear. The influence of finance on poverty has been mostly indecisive and vague from the empirical front due to the change in the level of income which results from financial sector reforms, which leads to poverty reduction in developing countries. In the developing countries, since economic progress leads to an increase in growth, the poverty reduction strategy will take more importance than the growth model, which does not necessarily improve the lives of the poor.

Bangladesh has been experiencing a modest reduction in the poverty rate of around $1.5 \%$ point a year for the last couple of decades (Vamvakidis \& Arora, 2010). The measure of poverty is also evident in improvement when it comes to distribution. Tensions mostly vanish. Researchers focus on financial sector reforms, reducing financial market imperfections to grow a discrete benefit to the individuals creates positivism, not negative and motivation effects (Ayyagari et al., 2007). Financial developments cannot stand on their own if favorable governmental policies do not immerse their development space to help economic growth. Growth is tantamount to poverty alleviation when it comes to developing policies.

Governmental policies are keynote when it comes to poverty alleviation. China, in recent years, is gradually taken millions of its people from absolute poverty. In analyzing issues in developing countries from 1966 to 2000, Visano (2008) and Jeanneney \& Kpodar (2008) concluded that the poor outweigh the cost when it comes to financial development and poverty alleviation comes to the benefit of financial development. Single country data analysis shows evidence of financial growth that is strongly connected with economic growth when dated from 286 Chinese cities surveyed from 2001-2006 after China enters into the world trade organization in 2001 (Zhang et al., 2012). Financial development per se, in its broader sense, affects poverty. The findings of the ARDL bounds testing approach from 1970-2015 reveal a stout long-run relationship between financial development, economic growth, inequality, and poverty in the contest of India (Sehrawat \& Giri, 2018). The study further shows unidirectional causality from financial development and economic growth to poverty, whiles inequality and poverty are bidirectional. Uddin et al. (2014) show a long-run relationship between economic growth and poverty reduction in Bangladesh. Financial developments reduce poverty but are not linear when quarter frequency data from 1975-2011.

Financial development proxy by broad money has exhibited several patterns in the selected countries coupled with their GDP growth rate (Olayungbo \& Quadri, 
2019). In their further studies, Olayungbo \& Quadri (2019), with the studies from 20 sub-Saharan African countries for 2000-2015, show that financial development and releases positively affect the economy in the short and long-run growth. The broad money (\% GDP) in Senegal, Mali, and the Gambia amounted to 45.2, 32.9, and 57.9 respectively, but with $3.9 \%, 7.2 \%$, and $-0.2 \%$ GDP annual growth rate in 2014 (WDI, 2018). Financial development contributes significantly to economic growth through straits of physical capital stock and total factor productivity when combining models and methods for cross-countries studies, for low-level, middle-income, and high in some countries (Ibrahim \& Alagidede, 2018). Similar studies conducted by Rousseau (2002) on the post-1850 period and modern economists after 1960; he found out the financial revolution using traditional and modern approaches suggests promoting trade, commerce, and industrialization, institutions, markets, and financial instruments plays a vital role. Conversely, studies from 15 African countries from 1995 to 2010, using static and dynamic panel data methods, suggested under endogenous stock market capitalization and foreign direct investment consistently have positive effects on economic growth (Assefa $\&$ Mollick, 2017). Growth can also use to lower poverty and leave the poor worse off relative to the average population. However, with counter studies from a different contest, the study concluded that growth reduces poverty no matter the level of inequality but further suggested that growth is not enough to alleviate poverty (Škare \& Družeta, 2016). Also, recent studies have examined the relationship among remittances, financial development, and economic growth from a different perspective without including poverty (Agbélénko \& Kibet, 2015; Audu et al., 2013; Beck et al., 2001; Sibindi, 2015).

The empirical literature reviewed above shows that previous studies have extensively focused on the relationship between financial development and economic growth and how these two variables impact poverty and other macroeconomic variables in developing countries. However, empirical investigation on the effects of financial development and economic growth using financial development as a transmission channel has not received adequate priority in the SSA countries. Furthermore, previous research works have not explicitly examined the short-run and long-run effects of financial development and economic growth on poverty in less-developed economies in general and SSA countries in particular. This study, therefore, intends to contribute to the literature by filling this gap.

In this paper, we expand upon this by asking whether financial development and economic growth separately alleviate poverty. We focus on extreme, absolute poverty is measured by household consumption in-line with other studies. In this context, this study will find out if there is a connection between financial development, economic growth, and poverty. A PMG approached was used to find out this connection for fourteen African countries. The studies speak in favor of the fact that as growth transpires, poverty reduces, no matter the level of inequality. Identically, a similar growth pattern has different effects on poverty reduction. The study concludes that growth is good for poverty alleviation, but it is not enough. The extent to which growth reduces poverty depends on how the study measures poverty, and upon the poor's absorptive capacity, the pace and pattern of growth. 


\section{Methods}

According to this study, 14 sub-Saharan African countries for the 1985 to 2017 data. Countries specification base on the population not less 20 million from the west, east, south, north, and central Africa. Some countries took out due to unavailable data, and others classify with other countries with a good standard of living. Data were taken from world development indicators (WDI) and Feenstra et al. (2015), that is, Penn world data files to help the researchers to come out with results. Financial development and economic growth are expected to positively impact poverty, with many studies conducted (Cepparulo et al., 2017). With this assertion, the study deploys a dynamic Granger causality test to trace the nexus between finance development, economic growth, and poverty reduction in Africa in the long run. All variables except variables in ratio forms have been transformed into natural logarithms (ln) to help stationarity in the matrix variance.

$Y_{i t}=A+\alpha_{1} g d p p l n_{i t}+\alpha_{2} g c f l n_{i t}+\alpha_{3} \operatorname{plcln}_{i t}+\alpha_{4} \operatorname{gexpln}_{i t}+\eta_{\mathrm{i}}+\mathcal{E}_{i t}$

Where $\mathrm{A}$ is the constant term, $\eta_{\mathrm{i}}$ is an unobserved country-specific effect, and $\varepsilon_{\mathrm{i}}$ is the error ${ }_{i}$ term and ${ }_{t}$ is the country and time respectively. This paper adopts the PMG ARDL method of estimations. Pesaran et al. (1999) proposed the PMG estimator associated with pooling and averaging of the coefficients over the cross-sectional units. The MG, on the other hand, involves estimating each unit separately and averaging the estimated coefficient over the cross-sectional units (Pesaran \& Shin, 1995) whiles the dynamic fixed effects (DFE) differ across groups. The PMG, which was strongly proposed by Pesaran et al. (1999), which is an intermediate estimator between MG and DFE involves both pooling and averaging with the long-run been homogeneous. The ARDL model is employed because of its adequacy to our data set. First, it can accommodate a mixture of stationarity of variables such as I (0) and I (1) and not I (2) like this study. This study contains 14 cross sections and 33 years, which is not bad for panel studies but can be taken care of in ARDL models. Finally, it captures the dynamics of the variable of interest in both the short run and the long run. Therefore, both the PMG and the MG estimations are carried out in this study. Equation (2) can be written in panel ARDL form of Pesaran et al. (1999) as the model is specified as the model is used for the same is as follows:

$\Delta Y_{i t}=\theta_{\mathrm{i}}\left[Y_{\mathrm{i}, t-1},-\lambda_{\mathrm{i},}^{\prime} \chi_{\mathrm{i}, t}\right]+\sum_{j=1}^{\mathrm{p}-1} \xi_{\mathrm{i} j} \Delta Y_{\mathrm{i}, t-j}+\sum_{j=\sigma}^{q-1} \beta_{\mathrm{i} j}^{\prime} \Delta X_{\mathrm{i}, t-j}+\varphi_{\mathrm{i}}+e_{i t^{t}}$

Where, $\theta_{\mathrm{i}}=-\left(1-\delta_{\mathrm{i}}\right)$, is the group-specific speed of adjustment coefficient (expected that $\left.\theta_{\mathrm{i}}<0\right)$ and $\lambda_{\mathrm{i}}^{\prime}=$ vector of long-run relationships. However, ECT $=\left[\mathrm{Y}_{\mathrm{i},}{ }_{t-1}-\lambda_{{ }_{\mathrm{i}},}, \chi_{\mathrm{i}},{ }_{t}\right]$, the error correction term that needs to be corrected within the equation. $\xi_{\mathrm{i}} j, \beta^{\prime}{ }_{\mathrm{i}} j$ are the short-run dynamic coefficients of the equations.

$$
\begin{aligned}
& \Delta g d p p_{i t}=\theta_{\mathrm{i}}\left[Y_{\mathrm{i}, t-1}-\lambda_{\mathrm{i},}^{\prime} \chi_{\mathrm{i}, t}\right]+\sum_{j=1}^{\overline{\mathrm{p}}-1} \varepsilon_{i j} \Delta g d p p_{\mathrm{i}, t-j}+\sum_{j=1}^{\overline{\mathrm{p}}-1} \pi_{\mathrm{i}} \Delta g c f \ln _{\mathrm{i}, t-j}+ \\
& \sum_{j=1}^{\overline{\mathrm{p}}-1} \psi_{\mathrm{i}} \Delta p \operatorname{lcln}_{\mathrm{i}, t-j}+\sum_{j=1}^{\overline{\mathrm{p}}-1} \omega_{\mathrm{i}} \Delta g \operatorname{expln}_{\mathrm{i}, t-j}+\sum_{j=1}^{\overline{\mathrm{p}}-1} \rho_{\mathrm{i}} \Delta g d p p l n+\sum_{j=1}^{q-1} \beta^{2}{ }_{i} \Delta g c f \ln _{i, t-j}+ \\
& \sum_{j=1}^{q-1} \beta^{3}{ }_{i} \Delta \operatorname{scln}_{i, t-j}+\beta^{4}{ }_{i} \Delta g \exp \ln _{i, t-j}+\varphi_{i}+e_{i t t}
\end{aligned}
$$


Where $\theta$ is the adjustment coefficient of the ${ }^{\mathrm{p}^{-1}}$ indicating the number of lags to be used for dependent variables $\xi_{i}, \pi_{i}, \psi_{i}, \omega_{i}$, and $\rho_{i}$ are the short-run coefficients while $\beta^{1}$ to $\beta^{4}$ indicates the long-run coefficients being the short run and the long run interactive effects of the gross domestic product per capita and gross capital formation being proxy for financial development. This shows how the model shows a correlation analysis

$r \frac{\left(\sum \chi \gamma\right)-\left(\sum \chi\left(\sum y\right)\right.}{\sqrt{\left.\left[n \sum \chi^{2}\right]\left(\sum \chi\right)^{2}\right]\left[n \sum y^{2}-\left(\sum y\right)^{2}\right]}}$

Once the correlation coefficient is a number from -1 to 1 or any number inbetween. If two data sets move in lockstep in the same direction and by the same amount, they have a correlation coefficient of 1 . If they move by the same amount but in the opposite direction, the number would be -1 . If the two sets of data seem to have no relationship at all, they correlate 0 .

\section{Results and Discussion}

Table 1 shows the measures of central tendency, mean, and median that give the center of the distribution estimates. It is evident that on average, GDP per capita, gross capital formation, household consumption, and government expenditure in the percentage of $6.819531 \%,-1.854619 \%-0.9888726 \%$, and $10.2336 \%$ respectively for the 14 countries.

Table 1. Summation of data

\begin{tabular}{cccccc}
\hline Variable & Observation & Mean & $\begin{array}{l}\text { Standard } \\
\text { deviation }\end{array}$ & Minimum & Max \\
\hline Gdppln & 462 & 6.819531 & 0.8191747 & 4.631275 & 8.596502 \\
Gcfln & 462 & -1.854619 & 0.6294697 & -4.378645 & -0.2935343 \\
Plcln & 462 & -0.9888726 & 0.352097 & -1.948901 & 0.3264126 \\
Gexpln & 462 & 10.2336 & 1.473431 & 7.077758 & 13.76809 \\
\hline
\end{tabular}

Source: Author elaboration

GDP per capita, gross capital formation, household consumption, and government expenditure are positively skewed, while only population growth is negatively skewed. It can observe that the standard deviation for government expenditure was the highest among the four variables. If the standard deviation exceeds $0.05 \%$, this is an indication that the null hypothesis of a normal distribution for the series rejects at this significance level. A maximum of $13.76809 \%$ indicates most SSA countries' understudy expenditure was high, while gross capital formation indicating a percentage of capital investment accumulation to the GDP was the lowest of $-4.378645 \%$.

Furthermore, Table 2 sections show an empirical connection between all the variables. There exist a positive relationship between all the variables under study. The conventional unit root tests such as ADF by Dickey \& Fuller (1979), PP by Phillips (1995), and Phillips and Perron (1988) have been widely used in macroeconomics 
dynamics and finance literature. This study will use to check the cross-section dependence, level of unit root, follow by padroni's cointegration test, Hausman test, and PMG-ARDL estimator to check the robustness of this study.

Table 2. Correlation analysis

\begin{tabular}{ccccc}
\hline Variables & Gdppln & Gcfln & PIcln & Gexpln \\
\hline Gdppln & 1.0000 & & & \\
Gcfln & 0.2996 & 1.0000 & & \\
Plcln & 0.3013 & 0.1773 & 1.0000 & \\
Gexpln & 0.2172 & 0.1166 & 0.2405 & 1.0000 \\
\hline
\end{tabular}

Source: Author elaboration

The study performs a test to analyze the independent, consistent with the coefficient estimates to ensure cross-sectional dependence in this panel data(Pesaran, 2020). The study adopts the cross-section dependence (CD) that supports larger crosssection $(\mathrm{N})$ and smaller time series $(\mathrm{T})$ like this study with $\mathrm{N}=14>\mathrm{T}=33$. The crosssectional dependence test in this section cannot reject at a $0.01 \%$ level of significance. This result implies that there is a presence of cross-sectional dependence in our data. Thus, to obtain unbiased estimates of our analysis, we conducted a diagnostic test by applying panel unit root tests in the presence of cross-sectional dependence on the residual estimates (Pesaran, 2007).

Table 3. Cross-sectional dependence

\begin{tabular}{cccccc}
\hline Variable & CD-test & P-value & Average joint T & Mean p & Mean abs (p) \\
\hline Ingdpp & 45.898 & 0.000 & 33.00 & 0.84 & 0.84 \\
Ingcf & 12.648 & 0.000 & 33.00 & 0.23 & 0.37 \\
Inplc & 25.121 & 0.000 & 33.00 & 0.46 & 0.59 \\
Ingexp & 43.995 & 0.000 & 33.00 & 0.80 & 0.81 \\
\hline
\end{tabular}

Notes: Under the null hypothesis of cross-section independence, $C D \sim N(0,1)$ P-values close to zero indicate data are correlated across panel groups.

This section corrects the test for only $\mathrm{I}(0)$ at the level and only $\mathrm{I}(1)$ variables at $1^{\text {st }}$ difference and not for $\mathrm{I}(2)$ at $2^{\text {nd }}$ difference variables (Pesaran, Shin, and Smith, 2001). In other words, panel unit root tests such as Levin Lin and Chu (LLC) (Levin et al., 2002), Im Pesaran and Shin (IPS) (So Im et al., 2003) tests were performed. Table 4 shows that all the variables not stationary at levels, meaning that they are I(0) variables using IPS whiles gross capital formation is stationary at 0.05 for LLC. However, all the variables were corrected at 1 st difference for IPS and LLC meaning all the variables are stationary at 1 st difference. Therefore, variables such as GDP per capita which was in line with the studies of Iheanacho (2016), Olayungbo \& Quadri (2019) and government expenditure for LLC follow I(1) process, while GDP per capita, gross capital formation, household consumption 
and government expenditure for IPS all was stationary I(1). These unit root results imply that the variables are mixed stationary, i.e., $\mathrm{I}(0)$ and $\mathrm{I}(1)$ processes that fit the PMG/ARDL model.

Table 4. Estimation of IPS and LLC Unit Root Test.

\begin{tabular}{lcccccccc}
\hline Variable & \multicolumn{4}{c}{ Im-Pesaran-Shin (IPS) } & \multicolumn{4}{c}{ Levin-Lin-Chu(LLC) } \\
\hline \multirow{3}{*}{ Gdppln } & Statistics & Level & Statistics & $1^{\text {st }}$ difference & Statistics & Level & Statistics & $1^{\text {st }}$ difference \\
Gcfln & 3.4884 & 0.9998 & -8.4408 & $0.0000^{* * *}$ & 0.7200 & 0.7642 & -6.9739 & $0.0000^{* * *}$ \\
PIcln & -0.6840 & 0.2470 & -12.8972 & $0.0000^{* * *}$ & -1.6512 & $0.0494^{* *}$ & -10.3206 & $0.0000^{* * *}$ \\
Gexpln & 0.0631 & 0.5252 & -12.6073 & $0.0000^{* * *}$ & -1.0965 & 0.1364 & -10.7558 & $0.0000^{* * *}$ \\
\hline
\end{tabular}

Note: *** Significant at the $0.01,{ }^{* *}$ Significant at the 0.05 level, *Significant at the 0.1 level Source: Authors elaboration (2019)

This section checks the properties of residual-based tests for the null hypothesis of no cointegration for dynamic panels in which both the short-run dynamics and the long-run slope coefficients permit to be heterogeneous across individual members of the panel. As shown in Table 5, the Padroni panel cointegration results disclose that 5 out of the padroni statistics significantly reject the null hypothesis of no cointegration.

Table 5. Padroni's co-integration tests:

\begin{tabular}{ccc}
\hline Test Stats. & Panel & Group \\
\hline V & 0.3026 & \\
Rho & -2.572 & -1.615 \\
T & -5.039 & -6.045 \\
Adf & -4.246 & -4.036 \\
\hline
\end{tabular}

Source: Author elaboration

Using the error correction term (ECT), the PMG estimation shows a long run for all the variables. A percentage increase in the coefficient of $(-0.1678347)$ will lead to a significant $0.0000^{* * *}$ at a 0.01 level for the GCF log. This result goes in line with the study of Khan et al. (2020), which suggested that GCF affects economic growth in South Asia's contest when looking from an infrastructure perspective.

The variable plc and gexp also show a sign of $0.0000^{* * *}$ for both at 0.01 level. Using causality to determine the long-run relationship for the three independent variables, the ECT results of the upper test of the PMG estimation shows the coefficients $(-0.1678347$, 0.08027586 and 0.8080295$)$ respectively have causal effects on the z-values of $0.0000^{* * *}$ at significant of 0.01 for all the variable of gcfln, plcln, and gexpln. Similar results were obtained when establishing cointegration, remittances and financial development have positive effects on economic growth both in the short and the long run (Olayungbo \& Quadri, 2019; Rana \& Barua, 2015). However, using the short run, the ECT was able to correct a model with a coefficient of $(-0.2364831)$ that will lead to a significant of $0.0000^{* * *}$ at 0.01 level. gcfln in the short run was not corrected at $0.01,0.05$, 
and 0.1 at all levels because it shows a significant of 0.745 . Other variables plcln and gexpln were corrected at all levels for a significant at $0.000^{* * *}$. This study was in line with Chen et al. (2020) and Saud et al. (2019), which identifies positive shocks in financial development that spur growth in the short run and negative shocks in financial development (government expenditure) that increase (reduce) growth. This indicates in the short run, there is no causality for gcfln on the z-values at 0.745 whiles, the plcln and gexpln have causal effects on the z-values of $0.000^{* * *}$.

Table 6. Pooled Mean Group Estimation

\begin{tabular}{lcccccc}
\hline \multicolumn{1}{c}{ D.gdppln } & Coefficient & SE & $\mathbf{Z}$ & $\mathbf{p}>[\mathbf{z}]$ & \multicolumn{2}{c}{ 95\% confident interval } \\
\hline \multicolumn{2}{l}{ Error correction term (ECT) } & & & & & \\
Gcfln & -0.1678347 & 0.0244781 & -6.86 & $0.0000^{* * *}$ & -0.215811 & -0.1198584 \\
PIcln & 0.8027586 & 0.0537021 & 14.95 & $0.0000^{* * *}$ & 0.6975044 & 0.9080129 \\
Gexpln & 0.8080295 & 0.0241061 & 33.52 & $0.0000^{* * *}$ & 0.7607824 & 0.8552766 \\
SR & & & & & & \\
ECT & -0.2364831 & 0.0665183 & -3.56 & $0.000^{* * *}$ & -0.366856 & -0.106109 \\
Gcfln D1. & 0.0151215 & 0.0465619 & 0.32 & 0.745 & 0.076138 & 0.1063811 \\
PIcln D1. & 0.5143777 & 0.0909034 & 5.66 & $0.000 * * *$ & 0.3362104 & 0.692545 \\
Gexpln D1. & 0.5290382 & 0.1333092 & 3.97 & $0.000^{* * *}$ & 0.267757 & 0.7903195 \\
Cons & -0.3768913 & 0.1881873 & -2.00 & $0.045^{* *}$ & -0.7457316 & -0.008051 \\
\hline
\end{tabular}

Notes: *** Significant at the 0.01 levels, ** Significant at the 0.05 level, ${ }^{*}$ Significant at the 0.1 level Source: Authors elaboration

Overall, this study shows that the effect of financial development and economic growth on poverty in SSA countries is different from what has been reported from other single and cross-country analysis in Africa and outside Africa. Specifically, the results are in with the study of Menyah et al. (2014) for 21 Africa countries, Uddin et al. (2014) observed for Bangladesh, Abdullahi et al. (2004) in the contest of West Africa, and Hassan et al. (2015) observed for Pakistan respectively, confirming the insignificant of financial development on poverty and economic growth on poverty as well. Therefore, the results highlight the specific features of this contest's variables as an intense way of reducing poverty in the studied African countries. Although other variables like trade openness are robust in alleviating poverty in Europe for 27 countries, according to Asteriou et al. (2013), vital variables prove financial development and economic growth effects on poverty.

From Table 7 , it tends to notice that there is a probability estimation of 0.08 , showing a significant value at a significant level of 0.1 . In these contests, because the probability value is 0.9942 , the null hypothesis cannot be rejected because the homogeneity issue is removed. The estimation tosses the nearness of a relationship between the individual effects and the independent variables at the 0.1 level. Therefore, the null hypotheses of the PMG chi2 (3) = (b-B)' $\left[\left(V_{-} b-V \_B\right) \wedge(-1)\right](b-B) 0.9942$ is accepted since it's $>0.05$ of the PMG estimator this study was in line with similar work of Saud et al. (2019). Therefore, these models support the PMG estimator. Based on the result of the Hausman test it can be noted that the pooled mean group model is appropriate for the model. 
Table 7. Hausman PMG, Sigmamore

\begin{tabular}{ccccc}
\hline & $\begin{array}{c}\text { (b) } \\
\text { Pmg }\end{array}$ & $\begin{array}{c}\text { (B) } \\
\text { DFE }\end{array}$ & $\begin{array}{c}\text { (b-B) } \\
\text { Difference }\end{array}$ & Sqrt(diag (V b-V_B)) S.E \\
\hline Gcfln & -1.168347 & -1.243159 & 0.0758813 & 0.7152561 \\
Plcln & 0.8027586 & 0.7561891 & 0.0465695 & 1.574213 \\
Gexpln & 0.8080295 & 0.9974809 & -0.1894514 & 0.7053691 \\
\hline
\end{tabular}

Source: Authors elaboration

\section{Conclusion}

The study mainly focuses on how we can marry the two to help reduce poverty in Sub-Saharan Africa. Within the same trace, financial development considerably will increase economic growth, and each helps to scale back economic conditions. Another contribution of this paper is to check the variations in each of the countries. There is a relation among the variables both in the long and short-run. The study also tends to found unidirectional causalities to running from economic growth to financial development and from financial development to economic growth in the short run and except for gross capital formation in the long run.

On the other hand, no causative relationship was found between government expenditure and financial development in SSA countries. This finding means a disconnection between financial development and government expenditure in SSA countries mirror in reducing economic condition. Therefore, this study concludes that each monetary development ends up in economic growth in the SSA region. However, the interrelatedness between financial development and the economic process does not matter within the growth process in SSA, thus economic condition.

The findings of this study have generated vital policy implications. The study observes that for a typical trapped-economy, gross capita formation precedes household consumption prices, which leads to expenditure. When the expenditure is channeled to the prices of household products, it leads to poverty reduction. The study from the financial perspective can help the banking sectors reduce expenses on their product to help their customers. This study observed that financial development does promote economic growth within the SSA countries within the initial instance. Firstly, the causative impact implies that the proximity of the growing abilities and investment opportunities at the home countries attract the massive flow of transfers from abroad to the SSA countries. Therefore governmental policies can be channeled to investors to reduce taxes to generate more investors to grow the economy. We disclosed that financial development might be a powerful tool to boost economic growth within the SSA countries with relation running from financial development to economic growth.

The policy recommendation is that improved financial services, financial instruments. Therefore, the payment systems are necessary for economic growth in SSA countries, each within the short and long run. The short and long-run monetary policies in SSA ought to be targeted towards improving the financial sector performance by developing sound financial reforms to deepen the financial sector. If these are well-reformed, it will 
lead to poverty reduction and reduce the burdens of the citizenry. There ought to be diversification of the banking services and augmented financial inclusion.

These suggested policies are framing the populace's need in these SSA countries related to the study area. The future challenges can reduce by taking some tough decisions at present, and the government should have to design a layout about poverty reduction and get a plan to integrate financial needs and growth of the economy as both are interlaced issues at the end of this pivot. The pro-poor growth and financial policies should design to reduce poverty by increasing gross capital formation. Thus the provision of technical knowledge should be given to the poorer.

\section{References}

Abdullahi, A. O., Safiyanu, S. S., \& Soja, T. (2004). Economic Growth and Poverty Reduction: Initial Conditions Matter. IOSR Journal of Economics and Finance, 7(2), 12-15. https://doi.org/10.9790/5933-07211215

Agbélénko, F. A., \& Kibet, K. S. (2015). Financial Development and Economic Growth in the West African Economic and Monetary Union ( WAEMU ). African Journal of Business Management, 9(17), 624-632. https://doi.org/10.5897/AJBM2015.7861

Assefa, T. A., \& Mollick, A. V. (2017). Financial Development and Economic Growth in Africa. Journal of Africa Business, 18(3), 320-339. https://doi.org/https://doi.or g/10.1080/15228916.2017.1301162

Asteriou, D., Dimelis, S., \& Moudatsou, A. (2013). Globalization and Income Inequality: a Panel Data Econometric Approach for the EU27 Countries. Economic Modelling, 36, 592-599. https://doi.org/10.1016/j.econmod.2013.09.051.

Audu, P. N., Okumoko, \& Pearce, T. (2013). Financial Development and Economic Growth in Nigeria. European Journal of Business and Management, 5(19), 69-82.

Ayyagari, M., Beck, T., \& Demirguc-kunt, A. (2007). Small and Medium Enterprises Across the Globe. Small Business Economics, 29, 415-434. https://doi.org/10.1007/ s11187-006-9002-5

Beck, T., Demirgüç-Kunt, A., \& Levine, R. (2001). Legal Theories of Financial Development. Oxford Review of Economic Policy, 17(4), 483-501.

Cepparulo, A., Cuestas, J. C., \& Intartaglia, M. (2017). Financial Development, Institutions, and Poverty Alleviation: an Empirical Analysis. Applied Economics, 49(36), 3611-3622. https://doi.org/10.1080/00036846.2016.1265074

Chen, H., Hongo, D. O., Ssali, M. W., Nyaranga, M. S., \& Nderitu, C. W. (2020). The Asymmetric Influence of Financial Development on Economic Growth in Kenya: Evidence From NARDL. SAGE Open, 10(1), 1-17. https://doi. org/10.1177/2158244019894071

Dhrifi, A. (2013). Financial Development and Poverty: What Role for Growth and Inequality? International Journal of Academic Research in Accounting, Finance and Management Sciences, 3(4), 119-129. https://doi.org/10.6007/IJARAFMS/v3-i4/362

Dickey, D. A., \& Fuller, W. A. (1979). Distribution of the Estimators for Autoregressive 
Time Series With a Unit Root. Journal of the American Statistical Association, 74(366), 427-431. https://doi.org/10.2307.2286348.

Feenstra, R. C., Inklaar, R., \& Marcel, P. T. (2015). The Next Generation of the Penn World Table. American Economic Review, 105(10), 3150-3182. https://doi.org/PWT 9.1

Hassan, S. A., Zaman, K., \& Gul, S. (2015). The Relationship Between GrowthInequality-Poverty Triangle and Environmental Degradation: Unveiling the Reality. Arab Economic and Business Journal, 10(1), 57-71. https://doi.org/10.1016/j. aebj.2014.05.007.

Ibrahim, M., \& Alagidede, P. (2018). Effect of Financial Development on Economic Growth in Sub-Saharan Africa. Journal of Policy Modeling, 40(6), 1104-1125. https:// doi.org/10.1016/j.jpolmod.2018.08.001.

Iheanacho, E. (2016). The Impact of Financial Development on Economic Growth in Nigeria: An ARDL Analysis. Economies, 4(4), 1-12. https://doi.org/10.3390/ economies 4040026

Khan, H., Khan, U., Jun, L., \& Asif, M. (2020). Impact of Infrastructure on Economic Growth in South Asia: Evidence from Pooled Mean Group Estimation. The Electricity Journal, 33(5), 106735. https://doi.org/10.1016/j.tej.2020.106735

Kodongo, O., \& Ojah, K. (2016). Does Infrastructure Explain Economic Growth in Sub-Saharan Africa? Review of Development Finance, 6(2), 105-125. https://doi. org/10.1016/j.rdf.2016.12.001

Levin, A., Lin, C., \& Chu, C. J. (2002). Unit Root Tests in Panel Data: Asymptotic and Finite-sample Properties. Journal of Econometrics, 108(1), 1-24.

Menyah, K., Nazlioglu, S., \& Wolde-rufael, Y. (2014). Financial Development, Trade Openness, and Economic Growth in African Countries: New Insights from a Panel Causality Approach. Economic Modelling, 37, 386-394. https://doi.org/10.1016/j. econmod.2013.11.044.

Olayungbo, D. O., \& Quadri, A. (2019). Remittances, Financial Development, and Economic Growth in Sub-Saharan African Countries: Evidence from a PMG-ARDL Approach. Financial Innovation, 5, 9. https://doi.org/doi.org/10.1186/s40854-019-0122-8.

Pesaran, M. H., \& Smith, R. (1995). Estimating Long-run Relationship from Dynamic Heterogeneous Panels. Journal of Econometrics, 68(1), 79-113. https://doi. org/10.1016/0304-4076(94)01644-F.

Pesaran, M. H., Shin, Y., \& Smith, R. P. (1999). Pooled Mean Group Estimation of Dynamic Heterogeneous Panels. Journal of the American Statistical Assocation, 94(446), 621-634. https://doi.org/10.2307/2670182.

Pesaran, M. H. (2007). A Simple Panel Unit Root Test in the Presence of Cross-section Dependence. Journal of Applied Econometrics, 22(2), 265-312.

Pesaran, M. H. (2020). General Diagnostic Tests for Cross Section Dependence in Panels. Empirical Economics. https://doi.org/10.1007/s00181-020-01875-7.

Phillips, P. C. B., \& Perron, P. (1988). Testing for a Unit Root in Time Series Regression. Biometrika Trust, 75(2), 335-346. https://doi.org/10.2307/2336182 
Benyamin Korankye. The Nexus Between Financial Development, Economic Growth

Phillips, P. C. B. (1995). Fully Modified Least Squares and Vector Autoregression. Economerica, 63(No.5), 1023-1078. https://doi.org/10.2307.2171721.

Rana, R. H., \& Barua, S. (2015). Financial Development and Economic Growth: Evidence From a Panel Study on South Asian Countries. Asian Economic and Financial Review, 5(10), 1159-1173.

Rousseau, P. L. (2002). Historical Perspectives on Financial Development and Economic Growth. National Bureau of Economic Research, 1(11), 21.

Saud, S., Chen, S., \& Haseeb, A. (2019). The Role of Financial Development and Globalization in the Environment: Accounting Ecological Footprint Indicators for Selected One-Belt-One-Road Initiative Countries. Journal of Cleaner Production, 250, 119518. https://doi.org/10.1016/j.jclepro.2019.119518

Sehrawat, M., \& Giri, A. K. (2018). The Impact of Financial Development, Economic Growth, Income Inequality on Poverty : Evidence from India. Empirical Economics, 55(4), 1585-1602. https://doi.org/10.1007/s00181-017-1321-7

Sibindi, A. B. (2015). Remittances, Financial Development, and Economic Growth: Empirical Evidence from Lesotho. Journal of Governance and Regulation, 5(10), 69-82. https://doi.org/10.18488/journal.aefr/2015.5.10/102.10.1159.1173

Škare, M., \& Družeta, R. P. (2016). Poverty and Economic Growth: a Review. Technological and Economic Development of Economy, 22(1), 156-175. https://doi. org/10.3846/20294913.2015.1125965

So Im, K., Pesaran, M. H., \& Shin, Y. (2003). Testing for Unit Roots in Heterogeneous Panels. Journal of Econometrics, 115(1), 53-74.

Jeanneney, S. G., \& Kpodar, K. R. (2008). Financial Development and Poverty Reduction: Can There Be a Benefit Without a Cost? IMF Working Paper African Department Financial Department Financial, 8, 38. https://doi.org/WP/08/62

Uddin, G. S., Shahbaz, M., Arouri, M., \& Teulon, F. (2014). Financial Development and Poverty Reduction Nexus: A Cointegration and Causality Analysis in Bangladesh. Economic Modelling, 36, 405-412. https://doi.org/10.1016/j.econmod.2013.09.049

Vamvakidis, A., \& Arora, V. (2010). China's Economic Growth: International Spillovers. IMF Working Paper, 10(165), 23. https://doi.org/WP/10/165

Visano, B. S. (2008). Different and Unequal: Payday Loans and Microcredit in Canada. The Journal of Economic Asymmetries, 5(1), 109-123.

WDI. (2018). World Development Indicators. The World Bank. Retrieved from http:// datatopics.worldbank.org/world-development-indicators/

Yang, F. (2019). The Impact of Financial Development on Economic Growth in Middleincome Countries. Journal of International Financial Markets, Institutions \& Money, 59, 74-89. https://doi.org/10.1016/j.intfin.2018.11.008

Zhang, J., Wang, S., \& Wang, S. (2012). Financial Development and Economic Growth: Recent Evidence from China. Journal of Comparative Economics, 40(3), 393-412. https://doi.org/10.1016/j.jce.2012.01.001. 